\title{
Client Assessment in Transactional Analysis - A Study of the Reliability and Validity of the Ohlsson, Björk and Johnsson Script Questionnaire
}

\author{
(C) 2011 Roland Johnsson
}

\begin{abstract}
A script questionnaire and associated checklist developed by Ohlsson, Johnsson \& Björk (1992) was used by the author and two professional colleagues to independently assess ten clients of a year-long transactional analysis therapy group conducted by the author. Ratings based on written responses at start of therapy were compared to ratings based on videotape interviews conducted by the author six years after termination of therapy. Moderately high inter-assessor reliability was found but intra-assessor reliability was low for the independent assessors; agreement increased for script components 'primary injunction from father,' 'racket feeling', 'escape hatch', 'driver from father' and 'driver from mother'.
\end{abstract}

\section{Key words}

script, script analysis, script interview, script questionnaire, reliability, transactional analysis (TA), transactional analysis group therapy.

Editor's Note: to allow for easier reading of the text of this paper, we have grouped all tables and figures together after the References and before the Appendices.

\section{Literature Review}

\section{The TA Concept of Script}

"The ultimate goal of transactional analysis is the analysis of scripts, since the script determines the destiny and identity of the Individual" (Berne, 1958, p. 737). Berne (1961) emphasised how scenes and experiences from early family drama are played out in everyday life in a specific and concrete way, similar to theatre dramaturgy, and argued that the task of therapy is to liberate the individual from the compulsion to repeat reliving the early script-bound scenes and thus start a new independent route in life. Although he defined script essentially as an "unconscious life plan for the individual based on decisions made in early childhood" (Berne, 1966, p. 300), he was not interested in therapies with long processes of transference and countertransference to raise an awareness of unconscious material. His method was allied with the client's functioning in the present, where the focus was mostly on processing the early message that the client could explicitly remember. He continued to develop the concept, culminating in a definition published posthumously (Berne, 1972) of script as "an on-going programme, developed in early childhood under parental influence, which directs the individual's behaviour in the most important aspects of his life" (p. 418).

Berne's approach was further developed by his colleagues and successors (English, 1972; Goulding \& Goulding, 1976, 1979; Steiner, 1967; Woollams, 1973). Steiner (1967) added the script matrix as a diagram showing how the ego states of the Child are impacted upon by injunctions, counterinjunctions, drivers and programme from the ego states of the parents. Readers unfamiliar with TA concepts are referred to Tilney (1998) for a glossary.

Steiner's matrix emphasised the functional clinical usefulness as it can be used to fill in the client's messages directly into the matrix. Other diagrams by Berne (1966), Goulding \& Goulding (1979) and Woollams \& Brown (1978) were more detailed and aimed at clarifying the theoretical developmental psychological aspect. Following an idea by Karpman (1966), Steiner (1967) complemented his visual matrix with a checklist where other script components were listed. Berne (1972) provided a script questionnaire comprising 220 questions; this was followed by questionnaires with fewer questions from authors such as James (1977), McCormick (1971) and Holloway (1973a).

Based on different versions of script questionnaires/ checklists, Ohlsson, Björk \& Johnsson (1992) designed, from their clinical experience, a script questionnaire with 43 questions (Appendix A) and a script checklist (Appendix B) including a script matrix with a checklist. These have been the work material for this study. Because of the various meanings given to the word 'script', it is suggested that the term as used in this paper refers to all of the items in this checklist and that, ideally, when talking about a person's script, the observer is referring to the whole checklist rather than to one or a few of the items. 
Comparable theories

Tomkins (1995a), originator of affect theory, posits nine early innate biological affects that are the foundation of our motivation to survive. When the little child communicates affects, the parents modulate these to an 'acceptable' level (Nathanson, 1992). Tomkins (1995b) makes clear that affects differ from emotions and feelings; the former are biology whereas the latter are linked to historical development and are interconnected with the individual's unique thoughts and memories, for which Tomkins (1978) also uses the term script.

Like Berne, Tomkins uses concepts and metaphors from the theatre, suggesting that feelings are organised on two levels as scenes and scripts. The scene is the basic unit, where the feeling is attached to an object (person), or a theme and an event with a beginning and an end. Tomkins' script refers to guiding principles for how the scenes are organised, and thus how specific or emotional experiences will be predicted, understood and controlled. As with TA theory, scripts can be adequate or destructive.

The cognitive theory concepts of schema (Perris, 1996), and RIGS (Representation of Interactions that have been Generalised) Stern (1991) have great similarities with Tomkins' (1978) script. They are all about individual-specific structures and patterns formed in childhood, which have subsequently guided the individual through life for good or bad. One difference is that Perris emphasises cognition while Berne, Stern and Tomkins underline the emotional interaction in early relationships and the ability to create and develop an internal object world.

TA script theory can also be linked to the psychoanalytical view on neurosis as an intra-psychic conflict (Fenichel, 1945, Haak, 1982). Small children come into conflict with the environment when they are frustrated in getting their operational needs satisfied. The conflict is pushed away, becomes unconscious and then fixated as a need at the time of the conflict. When, at times of crisis later in life, the individuals want to regain their inner balance, they regress to the point of fixation. The ego resolves the conflict by creating a symbolically designed compromise formation, the neurotic symptom. This is the solution Berne called the early decision, which is the basis for script formation.

In a number of studies, TA has been compared with other treatment methods (Goodstein, 1971; Ohlsson, 2010; Novey, 1999; Shaskan, Moran \& Moran, 1981) where the script application of TA therapy resulted in positive outcomes.

\section{Diagnosis}

The problem with TA diagnoses is that there is no standardisation or precision in the concepts and therefore it is uncertain whether the diagnosis has relevance (validity) in relation to the treatment process. As with most therapies, TA diagnoses are not regularly tested to achieve consistency between TA and non-TA practitioners. However, the communicability to the client and the usefulness are considered satisfactory without confirmation by a research context.

Widdowson (2010) has shown that many TA therapists use the DSM-IV or ID 10 diagnostic system in addition to their TA diagnosis. ID 10 is vaguely classified, while the DSM IV has clear behavioural criteria and can serve as a symptom classification instrument. Stewart (1996) found that DSM and ID classifications are not appropriate for practitioners because of contrasting opinions of how health problems should be described and of their narrow focus on the client's symptoms. Diagnoses do not usually follow a formally structured methodology and therapists also draw their conclusions from the informal process-oriented dialogue with the client (Cornell, 2008), in which the therapist emphasises the observation of oneself, one's feelings, memories and thoughts, so-called counter-transference. (Novellino, 1984, Hargaden \& Sills, 2002). The diagnosis is then used initially in a wider sense.

The psychodynamically developed OPD-2, Operationalized Psychodynamic Diagnostics (2008), has been identified as an appropriate and well-developed diagnosis instrument, well tested in a series of reliability and validity studies. It would be important for TA practitioners to link to other systematic classifications and pragmatically create congruence between the systems. The knowledge that it is possible to describe poor health in more ways is basically fruitful and can compensate for the risk that the diagnosis has a negative effect of becoming a selffulfilling prophecy, especially for those who believe that a diagnosis always has an organic basis and a disease. An attempt to combine diagnostic descriptions based on TA and DSM has been made by Stewart \& Joines (2002) including a classification of different personality adaptations. It has become widespread among TA practitioners but has not been researched in detail.

\section{Aims of the study and questions posed}

The aim of this study was to make client assessments, using interviews with a script questionnaire, by identifying central key conflicts in accordance with TA script theory and to examine the reliability of those analyses. The TA script theory can be viewed as a methodological theory and as an intervening variable. 
The following research questions were posed:

1. Is there agreement between script analyses made on two separate occasions, on the same client and made by the same assessor (intra-assessor reliability)?

2. Is there agreement between script analyses made on two separate occasions, on the same client and by different assessors (inter-assessor reliability)?

\section{Ethical permission}

The research was conducted under the provisions of Protocol 104-2 (Forskningsetikkommittén (2002), from the Ethical Research Committee of Lund Universities meeting 20 March 2002, confirming ethical permission to use the clinical material for research.

\section{Methodology}

The study subjects were 10 clients who had sought therapy voluntarily and attended a one-year, 24 sessions of two and a half hours TA therapy group with the author as psychotherapist. They responded to the 43 question script questionnaire and checklist (Appendices A \& B) at T1 - start of therapy and T2 six years later. At T1 they answered the written questionnaire themselves on the basis of instructions given by the author at the first session and submitted the completed questionnaires at the next therapy session. At T2, the author acted as interviewer, using the same questions and instructions as at T1. These interviews were videotaped.

The final material consisted of nine completed script questionnaires and ten videotaped script interviews. Analyses were made on both occasions by the author and by two independent assessors separately; all three were licensed psychotherapists and formally educated transactional analysts (TSTA-P Teaching and Supervising Transactional Analyst in the Psychotherapy field) with extensive experience as trainers and psychotherapists.

A total of 57 individual analyses were completed in which 26 different script components were assessed at each analysis. A series of tables are included. Assessors coded $1^{\text {st }}, 2^{\text {nd }}$ and $3^{\text {rd }}$ drivers from five, and made choices from 12 possible injunctions (Goulding \& Goulding, 1976), three potential positions on the drama triangle (Karpman, 1968), four life positions (Berne 1972) and three variants of escape hatches (Holloway, 1973b). Other components were formulated freely. Each client was described with a document that assembled all the data from the assessments on the two occasions (see example Table 1).

Based on each client's version of Table 1, versions of Table 2 were created to show reliability of interassessor and intra-assessor agreement. The sum- mary of these results is shown in Table 3 and illustrated graphically in Figure 1. In order to calculate the percentage agreement, full agreement between the three assessors was scored 3 , partial agreement 2, zero for no agreement, and a hyphen was used to indicate missing assessment items. The percentage agreement was calculated as a simple and direct measure of reliability with no adjustment for random agreement in the coding. This adjustment was made at a later stage (Tables 5-8) when the kappa coefficients according to Fleiss (1971) were calculated for a sample of primary script components. Tables 910 focus on intra-assessor reliability.

\section{Reliability considerations}

Sources of error with humans as measuring instruments are numerous and create well known reliability problems (Armelius \& Armelius, 1985). In this study these problems were addressed by using comparisons of assessments from well-trained and experienced transactional analysts (inter-assessor reliability) and assessments on several occasions (test-retest reliability or intra-assessor reliability). The complexity of the rating procedure contributed to reducing the reliability, whereas providing direct observations of the script interviews on the second assessment gave assessors access to significant phenomenological data as if they had been there.

As the therapist conducted the video interviews himself, a clear, confident and trusting situation was created for the client. The six-year interval meant results would be influenced by the client's maturity, development and possibly by other treatments; however the long gap would decrease the client's memory of previous answers given.

Therapist adherence to methodology has been linked to important positive outcomes by Luborsky et al (1985) but the TA therapy provided in this study did not follow a specific manualised treatment procedure (adherence), and the theoretical and operational definitions of script and its different components are qualitative and multidimensional. Clinical practice in TA requires a constantly modified observational process, making it more difficult to be confident of assessor reliability in statistical terms. A logicaldeductive approach was used, whilst being aware of subjective and qualitative elements in the definitions and observations that were used.

\section{Validity considerations}

Cook \& Campbell (1979) discuss problems that may occur with different types of validity. The operationalisation of the theoretical definitions of the concepts is rooted in clinical practice so construct validity is complex. Content validity has never been tested empirically, but has been assessed according to face validity by the different TA therapists. The interviews and assessments indicated that the so-called face validity was good, as the validity of the motivation, 
trust and knowledge of script questionnaires validity was high among interviewers and interviewees. The therapy room where the interviews took place and the direct contact between the therapist/interviewer and the client may in this context be regarded as an authentic environment with good ecological validity (Shadish, Cook \& Campbell, 2002). In the video the assessors could see how the clients reacted and responded to the interview questions. This on-line validation was built into the interview dialogue and has been used in other studies such as family therapy (Gustl et a., 2007; Sundell, Hansen, AndréeLöfholm et al, 2006).

In a mainly qualitative study, it becomes important to describe how data have been collected and processed in a systematic manner (internal validity). The script interview in the study was compiled by the assessors and used in a clinical context over a 25-year period, so may be regarded as relevant and reliable for its intended purpose.

In clinical research the 'truth' is highly linked to practical implications so we needed to take into account the therapeutic movement or process. Kvale (1987), Polkinghorne (1983) and Malterud, (1998), report communicative and pragmatic validity as two relevant criteria; these were reflected through a careful and detailed description of how the key elements of the research took place so the reader has the opportunity to consider the transferability of the approach to similar situations (external validity).

\section{Results}

Tables 1 and 2 are presented here as examples of how results were summarised and worked with.

Inter-assessor reliability

The summary in Table 3 indicates that there are small variations between the two occasions. At T1 the average agreement is $59 \%$ and at T2 it is $53 \%$.

The total script

The assessors' agreements for the analysis of each client's total script are shown in Figure 1. The difference in client assessments is at most $24 \%$ on both occasions. There is a variation in reliability of $49-73 \%$ at T1 and $41-60 \%$ at T2. The similar matching between the assessors on the two assessment occasions for each client is acceptable. The assessors do not show any significant difference in the agreement of client assessments over time.

\section{Individual script components}

An estimation of each script component separately (Table 3) shows that the coherence of assessments of the various components is mixed. For example, the correlation at T1 varies from $0 \%$ (the specifics of Games) to $85 \%$ (Life position) and at T2 from $0 \%$ (Counterinjunction 2 from mother) to $90 \%$ (Real feeling 1 ).
Script components with fixed defined categories like Driver, Injunction, Game/Drama-triangle, Life position and Escape hatch, have a higher percentage coherence compared to open categories. Especially low accordance is found in the coding of specified Games and different Counterinjunctions. The open categorisation of Racket feeling and Real feeling is an exception and has relatively high accordance.

The most significant primary components (Counterinjunction 1, Driver 1, Injunction, 1) have slightly higher coherence than the secondary and tertiary ones (e.g. Counterinjunction 2, Driver 3). This is apparent in the examination of the primary components in Tables 4-7.

The agreement between the two occasions is generally lower if one considers the individual components compared with assessments of the total script.

Primary script components

In a second examination of the material the focus was on the script components occurring in the clients that were most obvious and most evident and, thus, were first observed (Counterinjunctions, Driver, Injunction 1, etc.). These 11 primary components (Table 4) were a starting point for a new reliability calculation based on both percentage agreement and kappa ratio.

Fleiss' kappa (1971) was used, which in contrast to Cohen's kappa is a statistical reliability measure to assess inter-assessor reliability between more than two assessors. The significance of the kappa value is determined both by the strength of the kappa quotient and by the number of categories. The kappa coefficient $(\mathrm{K})$ is adjusted for randomness, as opposed to the percentage agreement (\%), which leads to a stronger consistency in the correlation.

The interpretation of the significance of the Fleiss kappa ratio has been made by Landis and Koch (1977). The distribution of the study's kappa quotas on the basis of their significance intervals is summarised in Table 5. A ranking of script components has been made for T1 (Table 6) and T2 (Table 7).

According to Wood (2007), in the research context there seems to be a general view that the kappa ratio should preferably be $0.60-0.70$, but that in certain cases, such as psychiatric diagnoses, a value of 0.40 and above may be acceptable. Nine categories are above 0.40 at T1 and six at T2. At T1 'Injunction from father', 'Racket feeling', 'Escape hatch' and 'Drivers from father' lie between $0.62-0.72$, while at T2 only 'Real feeling' and 'Game/Drama triangle' attain such values (0.66-0.69). 'Counterinjunction 1' from mother and father has a low value on both occasions $(0.15$ to 0.39). The largest difference in the ratio between the two sessions relates to 'Injunction from father' with a value of 0.72 or 0.29 . The total average for all of the components has a kappa ratio of 0.48 . 
Intra-assessor reliability

The assessors made two analyses of each client at different times. Tables $8 \mathrm{a}, 8 \mathrm{~b}$ and Figure 2 show that the ability to make a similar script analysis for the assessors in total is $67 \%$ for one of the assessors (C) and significantly lower, $33 \%$ and $39 \%$, respectively, for the other two (A and B). Looking at the overall agreement based on each client, differences of 25$30 \%$ are found. Client 2 had the highest accordance $(63 \%)$ between the two assessments, while Client 9 had the lowest $(31 \%)$. Even an examination of the specific percentage numbers gives a picture of wide variation $(20-70 \%)$ in the coherence of assessor analyses on the two occasions. Overall, it can be concluded that factors related to both the client and the assessor affect the result when assessments are made with a relatively long period in between (six years).

Ranking the results of Table $8 a$ into Table $8 b$ shows that the assessors have maximum coherence for clients 2 and 3 , and lowest coherence for client 9 .

\section{Discussion}

The aim of the study was to assess whether you can make a diagnostically reliable script analysis using a script questionnaire. This was done by examining, with the help of two interviews, the assessors' ability to agree on client assessments. The focus was partly tied to how well the assessments match for each assessor over time (intra-assessor reliability) and partly to agreement in their analyses of the clients' total scripts and the individual components of the scripts (inter-assessor reliability). With those two measures of reliability, an indication was given of how well the script analysis on the basis of script questionnaires serves as an assessment instrument.

Intra-assessor reliability.

The results show that assessors $A$ and $B$, without any detailed knowledge of the client, made different assessments on the two occasions. Assessor C, who is the therapist and author, had much higher agreement in his two perceptions of the clients' script, which indicates that a knowledge about the client may result in more consistency in analysis although it could also mean that the assessor failed to pick up on changes. In line with Orlinsky \& Howard (1986) the large discrepancy between the reliability of different client assessments may indicate that personal variables of the client and/or assessor can play a major role in the assessment.

One explanation for the relatively low coherence is that the client has changed over time. The therapy goal and ambition is to help to change the client's script. Hence, in a successful therapy the script should not be coherent over time. Conversely, responses to the script questions could become similar even if you have changed. Most of the questions are in the nature of memories of historical events and can be expected to give similar responses, regardless of the time factor. Another possible factor is that client assessment is unreliable, because of validity problems.
Inter-assessor reliability

When we combine all assessors' script analyses at both times and compare them with each other, the result is almost acceptable in relation to the literature. The overall correlation is $56 \%$ and relatively evenly distributed for each client. Given the difficulties with assessments over time as discussed, the overall reliability is surprisingly good. One influencing factor may be that the three assessors have worked together for a long time and have created a similar frame of reference in assessing clients. This convergence is likely to also affect the assessors' assessments over time, but becomes clearer from a general context.

When the reliability of the assessors' analysis of individual script components is examined, a considerable variation in the values is found, with the fixed categories giving better coherence than the open ones. Reliability increases significantly when examining only the 11 primary script components. More than half of those have moderate to substantial agreement and, overall, this more restrictive analysis obtains a higher reliability than the analysis of all 26 components. This is not surprising in any way but shows the difficulty of increasing the level of detail in the assessments whilst making an accurate analysis. It also shows that the gap decreases when going from the specific components to the total overall script.

There seems to be a need for an official standardised diagnostic system that can increase the reliability of psychotherapy assessments. With explicit criteria it would be easier to design and evaluate instruments that facilitate problem-formulating diagnostics (ratings and structured script interviews) and treatment followup (contract fulfilment). Explicit criteria would also facilitate communication between researchers, psychotherapists and clients. Finally, a clear categorical system would function as a base for decisions about mutual contracts, interventions, and well thought out treatments. Hopefully, the TA method will be researched more, and on the basis of specific descriptions and evaluation measures an alternative diagnostic classification system may subsequently develop built on whichever are the latest editions at the time of DSM, ICD or OPD, [Diagnostic \& Statistical Manual, American Psychiatric Association; International Classification of Diseases, World Heath Organization,; Operationalized Psychodynamic Diagnosis: Manual for Disorders and Treatment Planning, OPD Task Force (Eds)] in which the pragmatic concepts of TA become meaningful.

Overall, it can be demonstrated that the script Interview constitutes a good and reliable basis for determining, with the help of a script checklist, a general client assessment. The ability to assess individual script components is shown to be significantly more difficult.

Roland Johnsson, lic. Psychologist, lic. Psychotherapist, MSc, MSW, MA, Teaching \& Supervising Transactional Analyst (Psychotherapy) can be contacted on roland@livsterapi.se 


\section{References}

Armelius, B-b \& Armelius, K. (1985). Psykoterapiforskning en introduktion. Kristianstad: Rabén \& Sjögren.

Berne, E. (1958). Transactional Analysis: A new and effective method of group therapy. The American Journal of Psychotherapy, 12, 735-743.

Berne, E. (1961). Transactional Analysis in Psychotherapy. New York: Grove Press.

Berne, E. (1966). Principles of Group Treatment. New York: Oxford University Press.

Berne, E. (1972). What Do You Say After You Say Hello? New York: Grove Press.

Cornell, W. F. (2008). Setting the Therapeutic Stage: The Initial Sessions. In Explorations in Transactional Analysis: The Meech Lake Papers. Pleasanton, CA: TA Press.

English, F. (1972). Sleepy, spunky and spooky. Transactional Analysis Journal, 2, 64-73.

Fenichel, O. (1945). The Psychoanalytic Theory of Neurosis. London: Routledge, Kegan \& Paul.

Fleiss, J. L. (1971). Measuring nominal scale agreement among many raters. Psychological Bulletin, 76 (5), 378-382.

Goodstein, M. (1971). A comparison of Gestalt and Transactional Analysis therapies in marathons. Ph.D. dissertation, Illinois Institute of Technology

Goulding, R. \& Goulding, M. (1976). Injunctions, Decisions and Redecisions. Transactional Analysis Journal, 6 (1), $41-48$.

Goulding, R. \& Goulding, M. (1979). Changing lives through Redecision Therapy. New York: Grove Press.

Gustle, L-H et al (2007). Blueprints in Sweden. Symptom load in Swedish adolescents in studies of Functional Family Therapy (FFT), Multisystemic Therapy (MST) and Multidimensional Treatment Foster Care (MTFC). Nordic journal of psychiatry.

Haak, N. (1982). Allmän neuroslära på psykoanalytisk grund. Stockholm: Natur \& Kultur.

Hargaden, H. \& Sills, C. (2002). Transactional Analysis: a relational perspective. Hove: Brunner-Routledge.

Holloway, W. (1973a). Clinical Transactional Analysis with Use of Life Script Questionnaire. Medina: Midwest Institute For Human Understanding.

Holloway, W. (1973b). Shut the Escape Hatch, no IV. The monograph series of Midwest Institute for Human Understanding no I-X. Medina: Midwest Institute For Human Understanding.
James, M. (1977). Techniques in Transactional Analysis for Psychotherapists and Counselors. Menlo Park: AddisonWesley.

Karpman, S. (1966). Teaching Transactional Analysis in Tgroups. Transactional Analysis Bulletin, 5 (20), 184-185.

Karpman, S. (1968). Fairy tales and script drama analysis. Transactional Analysis Bulletin, 7 (26). 39-43.

Kvale, S. (1987). Validity in the Qualitative Research Interview. Methods, 1 (2).

Landis, J. R. \& Koch, G. G. (1977). The measurement of observer agreement for categorical data. Biometrics, 33 , 159-174.

Luborsky, L., McLellan, A. T., Woody, G. E., O'Brien, C. P. \& Auerbach, A. (1985). Therapist success and its determinants. Archives of General Psychiatry, 42, 602-611.

Malterud K. (1998). Validitet. Kvalitativa metoder i medicinsk forskning. Lund: Studentlitteratur.

McCormick, P. (1971). Guide for Use Of Life Script Questionnaire in Transactional Analysis. Berkeley: Transactional Pubs.

Nathanson, D. L. (1992) Shame and Pride. Affect, Sex and the Birth of Self. New York: W.W. Norton \& Company.

Novellino, M. (1984). Self-analysis of counter-transference. Transactional Analysis Journal, 14 (1) 63-75.

Novey, T. (1999). The effectiveness of transactional analysis. Transactional Analysis Journal, 29, 18-30.

Ohlsson, T. (2010) Scientific evidence base for transactional analysis in the year 2010. Annex 2 - the Psychotherapy List: References to research on Transactional Analysis psychotherapy effects 1963-2010. International Journal of Transactional Analysis Research, 1 (1), 24-29.

Ohlsson, T., Björk, A. \& Johnsson, R. (1992). Transaktionsanalytisk psykoterapi. Lund: Studentlitteratur.

OPD Task Force (Eds.). (2008). Operationalized Psychodynamic Diagnosis OPD-2: Manual for Diagnosis and Treatment Planning (2nd Revised ed.). New York: Hogrefe \& Huber.

Orlinsky, D. E. \& Howard, K. I. (1986). Process and outcome in psychotherapy. In S. Garfield \& A. Bergin (Eds.), Handbook of psychotherapy and behavior change (3rd ed.). New York: Wiley.

Perris, C. (1996). Kognitiv terapi i teori och praktik. Stockholm: Natur \& Kultur.

Polkinghorne, D. E. (1983). Methodology for the human sciences. Albany: SUNY Press. 
Shadish, W., Cook, T. D. \& Campbell, D.T. (1979). Quasiexperimentation: Design and Analysis Issues for Field Settings. Boston: Houghton-Mifflin.

Shaskan, D., Moran, W. \& Moran, O. M. (1981). Influence of group psychotherapy: A thirty year follow-up. Transactional Analysis Journal, 11, 270-274.

Steiner, C. (1967). A Script Checklist. Transactional Analysis Bulletin, 6 (22), 38-39.

Steiner, C. (1976). Beyond Games and Scripts by Eric Berne - Selections from his major writings. New York: Grove Press.

Stewart, I. (1996). Developing transactional analysis counselling. London: Sage.

Stewart, I. \& Joines, V. (2002). Personality adaptations - A New Guide to Human Understanding in Psychotherapy and Counselling. Nottingham and Chapel Hill: Lifespace Publishing.

Sundell, K., Hansson, K., Andrée-Löfholm, C. et al (2006). Multisystemisk terapi för ungdomar med allvarliga beteendeproblem. Stockholm: Socialstyrelsen.

Tilney, T. (1998). Dictionary of Transactional Analysis. London: Whurr Publishers.
Tomkins, S. S. (1978). Script Theory: Differential magnification of Affects. In Nebraska Symposium on Motivation (1979), 201-233. Lincoln: University of Nebraska Press.

Tomkins, S. S. (1995a). The quest for primary motives. In E. V. Demos, (Ed.) Exploring Affect. The Selected Writings of Silvan S. Tomkins, 27-63. New York: Cambridge University Press.

Tomkins, S. S. (1995b). Role of the specific affects. In E. V. Demos, (Ed.) Exploring Affect. The selected writings of Silvan S. Tomkins, 68-85. New York: Cambridge University Press.

Widdowson, M. (2010). Transactional Analysis: $100 \mathrm{Key}$ Points. London: Routledge.

Wood, J. M. (2007, October 3). Understanding and Computing Cohen's Kappa: A Tutorial. http://www.wpe.info/vault/wood07/Wood07.pdf Retrieved on $12 / 06 / 2011$.

Woollams, S. (1973). Formation of the script. Transactional Analysis Journal, 3, 31-37.

Woollams, S. \& Brown, M. (1978). Transactional Analysis. Dexter: Huron Valley Press. 


\section{Tables and Figures}

Table 1: Example: Summary of assessments for a client

\begin{tabular}{|c|c|c|c|c|c|c|}
\hline \multirow{2}{*}{$\begin{array}{l}\text { Client } 1 \\
\text { Script components }\end{array}$} & \multicolumn{2}{|c|}{ Assessor A } & \multicolumn{2}{|c|}{ Assessor B } & \multicolumn{2}{|c|}{ Assessor C } \\
\hline & T1 & T2 & T1 & T2 & T1 & T2 \\
\hline \multicolumn{7}{|l|}{ Mother: } \\
\hline Counterinjunction 2 & & & Please others & Be kind & - & \\
\hline Driver 1 & Be strong & Be strong & Please others & Be strong & Be strong & Be strong \\
\hline Driver 2 & Try hard & & & & Try hard & Try hard \\
\hline Injunction 1 & Don't be close & Don't be close & Don'tbe important & Don't be close & Don't be close & Don't be close \\
\hline Injunction 2 & & Don't be a child & Don't be a child & Don't belong & Don't belong & Don't be a child \\
\hline \multicolumn{7}{|l|}{ Father: } \\
\hline Counterinjunction 1 & & Be funny & Work hard & Be funny & Be funny & Be funny \\
\hline Counterinjunction 2 & & & & Be happy & Be happy & \\
\hline Driver 1 & Try hard & & Be perfect & & Be perfect & Be perfect \\
\hline Driver 2 & Please others & Please others & & Please others & Please others & Please others \\
\hline \multicolumn{7}{|l|}{ Driver 3} \\
\hline Injunction 1 & Don't think & Don't think & Don't belong & Don't grow up & Don't belong & Don't belong \\
\hline Injunction 2 & Don't feel & Don't be close & Don't be close & Don't feel & Don't feel & Don't feel \\
\hline Early decisions & $\begin{array}{l}\text { To be happy } \\
\text { and kind on the } \\
\text { outside but } \\
\text { hiding the inside }\end{array}$ & $\begin{array}{l}\text { Be generous, } \\
\text { funny, please } \\
\text { others to } \\
\text { distance your } \\
\text { loneliness, }\end{array}$ & $\begin{array}{l}\text { Lonely must } \\
\text { take care of } \\
\text { myself. Nobody } \\
\text { believes in me. }\end{array}$ & $\begin{array}{l}\text { Be happy and } \\
\text { strong take care } \\
\text { of mum's } \\
\text { discontent and } \\
\text { father's fear for } \\
\text { feelings }\end{array}$ & $\begin{array}{l}\text { Be strong and } \\
\text { tough not } \\
\text { showing } \\
\text { feelings but } \\
\text { suffer in silence }\end{array}$ & $\begin{array}{l}\text { Please others } \\
\text { withdraw so } \\
\text { others can avoid } \\
\text { feelings so not } \\
\text { to feel lonely }\end{array}$ \\
\hline Racket feeling 1 & worried/fear & lonely & worried/fear & happy & worried/fear & lonely \\
\hline Racket feeling 2 & sadness & sadness & guilt & & guilt & sadness \\
\hline Real feeling 1 & angry & angry & angry & angry & angry & angry \\
\hline Real feeling 2 & & & sad & sad & & \\
\hline Game/drama triangle & Rescuer & Rescuer & Victim & Rescuer & Rescuer & Rescuer \\
\hline Specific game & $\begin{array}{l}\text { I'm Only Trying } \\
\text { To Help You }\end{array}$ & Rapo, Clown & & & & \\
\hline Life position & $\begin{array}{l}\text { I'm not OK-You } \\
\text { are OK }\end{array}$ & $\begin{array}{l}\text { I'm not OK-You } \\
\text { are OK }\end{array}$ & $\begin{array}{l}\text { I'm not OK-You } \\
\text { are OK }\end{array}$ & $\begin{array}{l}\text { I'm not OK-You } \\
\text { are OK }\end{array}$ & $\begin{array}{l}\text { I'm not OK-You } \\
\text { are OK }\end{array}$ & $\begin{array}{l}\text { I'm not OK-You } \\
\text { are OK }\end{array}$ \\
\hline Escape hatch & Not open & Not open & suicide & Not open & Not open & Not open \\
\hline Specific & addiction & & & Be a loner & Be a loner & Be a loner \\
\hline
\end{tabular}


Table 2: Examples of inter- and intra-assessor reliability for Client 1

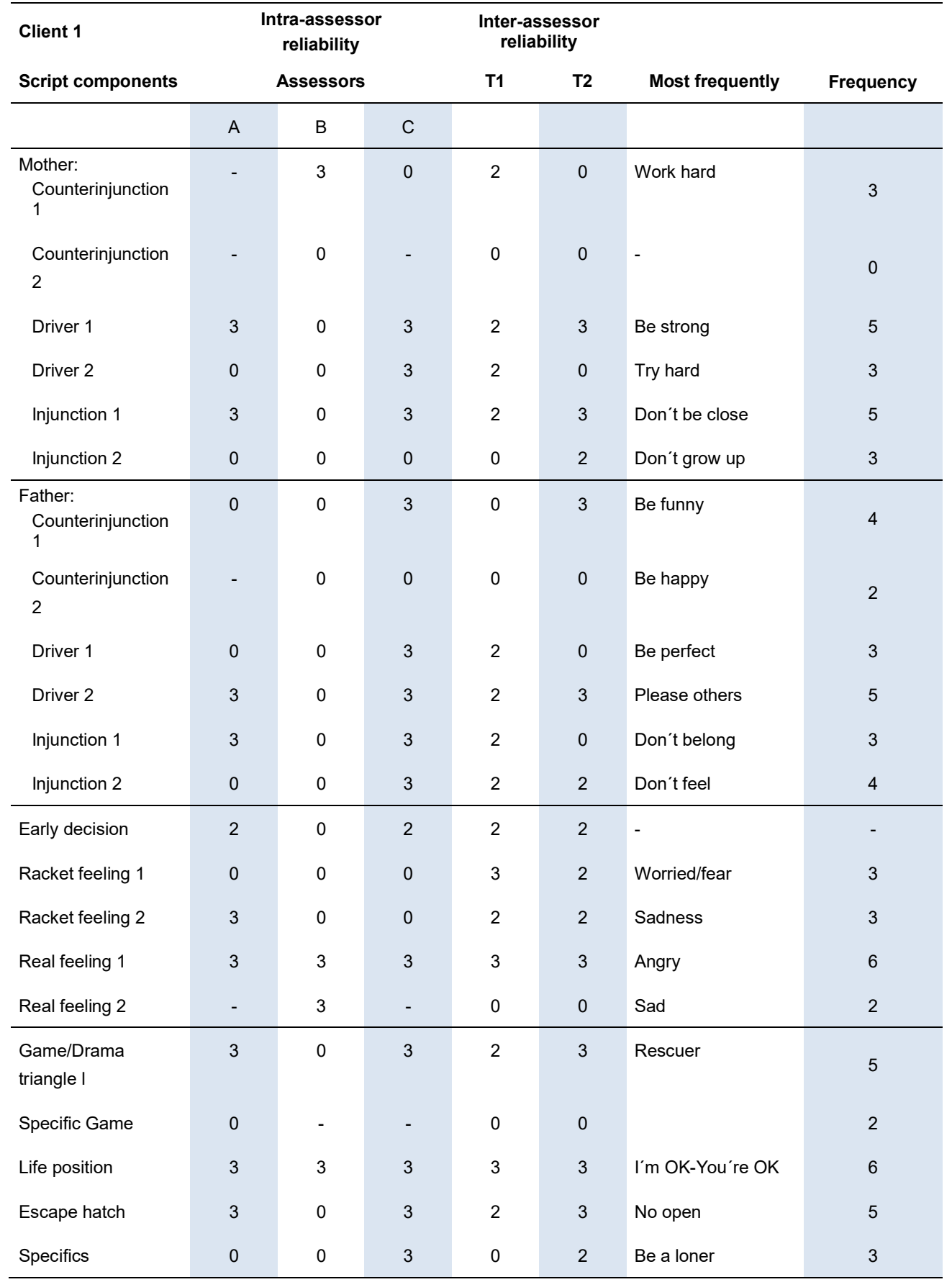

Note. $3=$ full agreement, 2 = two of three agreed, $0=$ no agreement, and $-=$ no assessment.

Most frequently $=$ the most frequent component, and Frequency $=$ number based on 0-6

possible assessments. 
Table 3: Percentage of inter-assessor reliability for all clients, components and total

\begin{tabular}{|c|c|c|c|c|c|c|c|c|c|c|c|c|c|c|c|c|c|c|c|c|c|}
\hline & \multicolumn{10}{|c|}{ T1 } & \multicolumn{11}{|c|}{ T2 } \\
\hline $\begin{array}{l}\text { Client } \\
\text { Component }\end{array}$ & 1 & 2 & 3 & 4 & 5 & 6 & 7 & 8 & 9 & $\%$ & 1 & 2 & 3 & 4 & 5 & 6 & 7 & 8 & 9 & 10 & $\%$ \\
\hline \multicolumn{22}{|l|}{ Mother: } \\
\hline Counterinjunction 1 & 2 & 0 & 2 & 2 & 3 & 0 & - & 2 & 0 & 46 & 0 & 0 & 0 & 2 & 2 & 0 & 0 & 0 & 0 & 0 & 13 \\
\hline Counterinjunction 2 & 0 & 2 & 0 & - & - & - & - & - & - & 22 & 0 & 0 & 0 & - & - & 0 & 0 & - & 0 & - & 0 \\
\hline Drivers 1 & 2 & 3 & 2 & 3 & 3 & 2 & 3 & 2 & 3 & 85 & 3 & 3 & 3 & 2 & 3 & 3 & 2 & 3 & 2 & 0 & 80 \\
\hline Drivers 2 & 2 & - & 2 & 2 & - & - & 0 & - & 2 & 53 & 0 & 0 & 0 & 2 & 0 & - & 3 & 0 & 3 & 3 & 40 \\
\hline Drivers 3 & - & - & - & - & - & - & - & - & - & - & - & - & - & - & - & - & - & - & - & - & - \\
\hline Injunction 1 & 2 & 0 & 2 & 2 & 3 & 2 & 3 & 2 & 0 & 59 & 3 & 2 & 3 & 2 & 0 & $2-$ & 0 & 3 & 2 & 3 & 66 \\
\hline Injunction 2 & 0 & 3 & 0 & 0 & 2 & - & 2 & 2 & - & 43 & 2 & 2 & 2 & 0 & 3 & 3 & 2 & 0 & 0 & 2 & 53 \\
\hline Injunction 3 & - & 3 & - & - & - & - & 2 & 2 & - & 78 & - & 3 & - & - & - & - & 3 & 3 & - & 2 & 91 \\
\hline \multicolumn{22}{|l|}{ Father: } \\
\hline Counterinjunction 1 & 0 & 2 & 0 & 0 & - & 0 & - & 3 & 0 & 23 & 3 & 2 & 3 & 0 & - & 0 & 0 & 0 & 0 & - & 33 \\
\hline Counterinjunction 2 & 0 & 0 & 0 & - & - & - & - & 2 & - & 17 & 0 & 2 & 0 & - & - & - & - & 0 & 0 & - & 13 \\
\hline Drivers 1 & 2 & 2 & 2 & 3 & 3 & 3 & 2 & 3 & 2 & 81 & 0 & 2 & 0 & 3 & 2 & 3 & 2 & 0 & 3 & 0 & 50 \\
\hline Drivers 2 & 2 & 0 & 2 & 0 & - & - & 0 & 0 & 0 & 19 & 3 & 0 & 3 & - & 0 & 0 & 0 & 0 & 0 & - & 25 \\
\hline Drivers 3 & - & - & - & - & - & - & - & - & - & - & - & - & - & - & - & - & - & - & - & - & - \\
\hline Injunction 1 & 2 & 3 & 2 & 3 & 3 & 3 & 3 & 0 & 2 & 78 & 0 & 2 & 0 & 3 & 3 & 2 & 2 & 2 & 3 & 2 & 63 \\
\hline Injunction 2 & 2 & 2 & 2 & 2 & 2 & 3 & 3 & 3 & 2 & 77 & 2 & 3 & 2 & 2 & 2 & 3 & 3 & 2 & 0 & 2 & 70 \\
\hline Injunction 3 & - & 3 & - & - & 0 & - & 2 & - & 0 & 41 & - & 0 & - & 0 & 0 & - & 0 & 0 & - & - & 0 \\
\hline Early decision & - & - & - & - & - & - & - & - & - & - & - & - & - & - & - & - & - & - & - & - & - \\
\hline Racket feeling 1 & 3 & 0 & 3 & 3 & 2 & 3 & 3 & 3 & 2 & 81 & 2 & 2 & 2 & 0 & 3 & 2 & 2 & 2 & 2 & 3 & 66 \\
\hline Racket feeling 2 & 2 & 0 & 2 & - & 2 & 0 & 3 & - & - & 50 & 2 & - & 2 & 0 & 3 & - & 3 & - & 2 & 0 & 57 \\
\hline Real feeling 1 & 3 & 2 & 3 & 2 & 0 & 3 & 3 & 0 & 3 & 70 & 3 & 3 & 3 & 2 & 3 & 2 & 3 & 3 & 2 & 3 & 90 \\
\hline Real feeling 2 & 0 & - & 0 & 2 & 2 & - & - & 2 & 0 & 33 & 0 & - & 0 & 0 & - & - & - & 3 & 0 & - & 20 \\
\hline Game & 2 & 3 & 2 & 3 & 2 & 3 & 2 & 3 & 2 & 81 & 3 & 3 & 3 & 3 & 3 & 2 & 3 & 3 & 2 & 3 & 93 \\
\hline Specific game & 0 & 0 & 0 & 0 & 0 & - & - & 0 & - & 0 & 0 & 0 & 0 & 0 & 2 & 0 & 2 & 0 & 0 & 0 & 13 \\
\hline Life position & 3 & 2 & 3 & 2 & 3 & 3 & 2 & 3 & 2 & 85 & 3 & 2 & 3 & 3 & 2 & 2 & 2 & 3 & 3 & 2 & 83 \\
\hline Escape hatches & 2 & 3 & 2 & 3 & 2 & 3 & 2 & 3 & 3 & 85 & 3 & 3 & 3 & 2 & 0 & 3 & 3 & 3 & 2 & 3 & 83 \\
\hline Specific & 0 & 2 & 0 & - & 2 & 2 & - & 2 & 2 & 48 & 2 & 2 & 2 & 2 & 0 & 2 & 0 & 2 & 0 & 3 & 50 \\
\hline Rating & - & - & - & - & - & - & - & - & - & - & 3 & 2 & 3 & 3 & 0 & 2 & 0 & 2 & 3 & 0 & 60 \\
\hline Total \% & 49 & 56 & 49 & 63 & 67 & 71 & 73 & 61 & 49 & 59 & 53 & 57 & 53 & 49 & 57 & 56 & 55 & 50 & 41 & 60 & 53 \\
\hline
\end{tabular}

Note. $0=$ not agreed, $2=$ two of three agreed, $3=$ all three agreed. $-=$ no assessment. Calculation Example: Counterinjunctions $1=2+0+2+2+3+0+2+0=11$. Divided with the number of assessments 5 , which is multiplied by the ideal situation where everyone agrees, that is 3 , which becomes $46 \%$.

Figure 1: Graph of assessors' percentage of agreement for each client's total script at 2 times of assessments

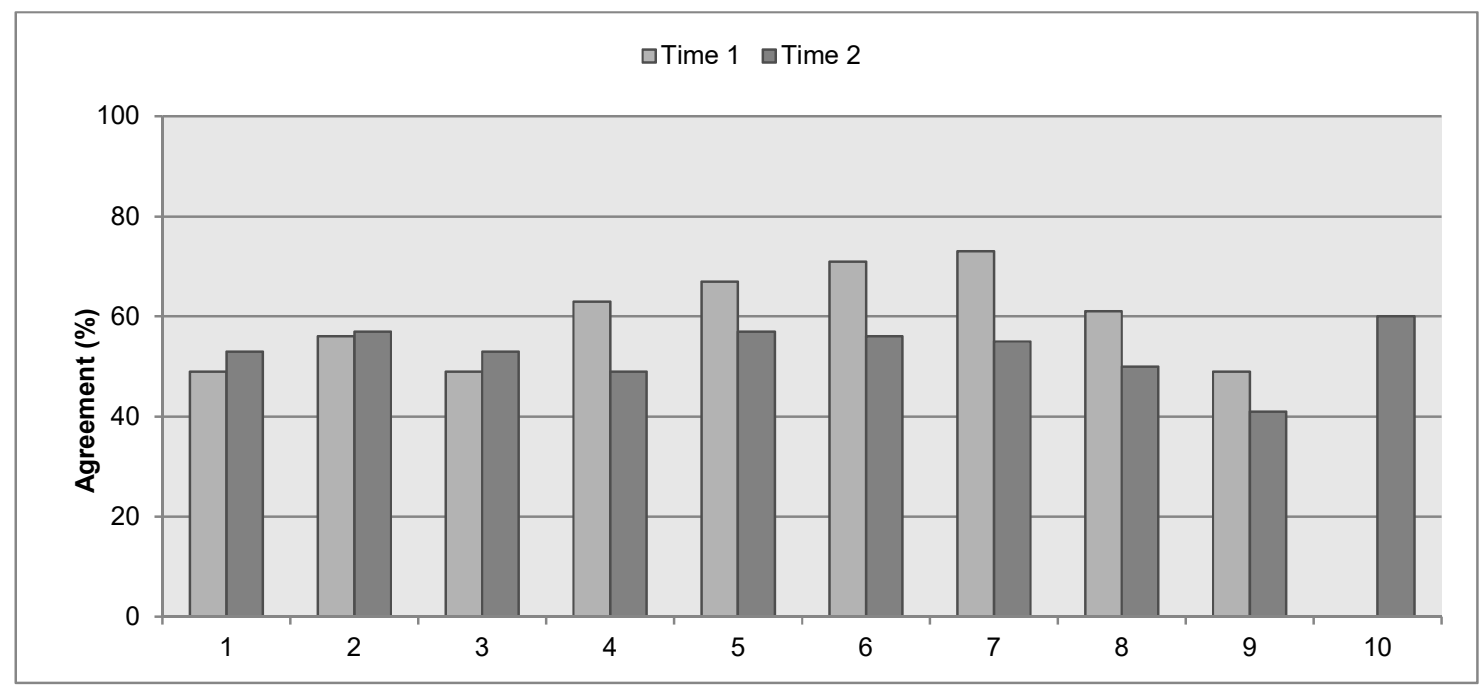


Table 4: kappa ratio and percentage agreement between the 3 assessors of 11 primary script components calculated for a total of 10 clients at the 2 assessment times

\begin{tabular}{|c|c|c|c|c|}
\hline \multirow[b]{2}{*}{$\begin{array}{l}\text { Script } \\
\text { components }\end{array}$} & \multicolumn{2}{|c|}{ T1 } & \multicolumn{2}{|c|}{ T2 } \\
\hline & $\begin{array}{l}\text { kappa } \\
\text { quota (k) }\end{array}$ & $\begin{array}{l}\text { Agree } \\
(\%)\end{array}$ & $\begin{array}{l}\text { kappa } \\
\text { quota (k) }\end{array}$ & $\begin{array}{l}\text { Agree } \\
(\%)\end{array}$ \\
\hline $\begin{array}{l}\text { Counterinjunction } \\
1 \text { from mother }\end{array}$ & ${ }^{*} 0.32$ & 70 & ${ }^{*} 0.15$ & 50 \\
\hline $\begin{array}{l}\text { Driver } 1 \text { from } \\
\text { mother }\end{array}$ & ${ }^{* *} 0.56$ & 86 & ${ }^{* *} 0.52$ & 86 \\
\hline $\begin{array}{l}\text { Injunction } 1 \text { from } \\
\text { mother }\end{array}$ & ${ }^{*} 0.43$ & 66 & ${ }^{* *} 0.46$ & 66 \\
\hline $\begin{array}{l}\text { Counterinjunction } \\
1 \text { from father }\end{array}$ & ${ }^{*} 0.38$ & 73 & ${ }^{* *} 0.39$ & 66 \\
\hline $\begin{array}{l}\text { Drivers } 1 \text { from } \\
\text { father }\end{array}$ & ${ }^{* *} 0.62$ & 86 & ${ }^{* *} 0.41$ & 70 \\
\hline $\begin{array}{l}\text { Injunction } 1 \text { from } \\
\text { father }\end{array}$ & ${ }^{* *} 0.72$ & 90 & 0.29 & 73 \\
\hline Racket feeling & ${ }^{* *} 0.68$ & 83 & ${ }^{* *} 0.49$ & 66 \\
\hline Real feeling & ${ }^{*} 0.51$ & 76 & ${ }^{* *} 0.66$ & 90 \\
\hline $\begin{array}{l}\text { Game/drama } \\
\text { triangle }\end{array}$ & ${ }^{* *} 0.48$ & 86 & ${ }^{* *} 0.69$ & 90 \\
\hline Life positioner & **0.44 & 86 & 0.36 & 83 \\
\hline Escape hatch & ${ }^{* *} 0.65$ & 90 & 0.38 & 90 \\
\hline
\end{tabular}

Note ${ }^{*} p<0.01{ }^{* *} p<0.001$ Counterinjunction $=$ primary Counterinjunction Average value is $\mathrm{K}=0.48$ and $78 \%$, respectively

Table 6: Ranking of script components for 10 clients at $T 1$ assessment

\begin{tabular}{|c|c|c|c|}
\hline Priority & Script components & $\begin{array}{c}\text { kappa } \\
\text { quota (к) }\end{array}$ & $\begin{array}{l}\text { Agreement } \\
(\%)\end{array}$ \\
\hline 1 & Injunction 1 from father & ${ }^{* *} 0.72$ & 90 \\
\hline 2 & Racket feeling & ${ }^{\star *} 0.68$ & 83 \\
\hline 3 & Escape hatch & ${ }^{* *} 0.65$ & 90 \\
\hline 4 & Drivers 1 from father & ${ }^{* *} 0.62$ & 86 \\
\hline 5 & Drivers 1 from mother & ${ }^{* *} 0.56$ & 86 \\
\hline 6 & Real feeling & ${ }^{*} 0.51$ & 76 \\
\hline 7 & Game/drama triangle & ${ }^{* *} 0.48$ & 86 \\
\hline 8 & Life position & ${ }^{* *} 0.44$ & 86 \\
\hline 9 & $\begin{array}{l}\text { Injunction } 1 \text { from } \\
\text { mother }\end{array}$ & ${ }^{*} 0.43$ & 66 \\
\hline 10 & $\begin{array}{l}\text { Counterinjunction } 1 \\
\text { from father }\end{array}$ & ${ }^{*} 0.38$ & 73 \\
\hline 11 & $\begin{array}{l}\text { Counterinjunction } 1 \\
\text { from mother }\end{array}$ & ${ }^{*} 0.32$ & 70 \\
\hline
\end{tabular}

Table 5: Distribution of kappa coefficients for 11 primary script components for 10 clients at the 2 assessment times

\begin{tabular}{|c|c|c|c|}
\hline $\begin{array}{l}\text { Intervals of } \\
\text { kappa } \\
\text { coefficients }\end{array}$ & $\begin{array}{l}\text { Interpretation of } \\
\text { intervals }\end{array}$ & $\begin{array}{l}\text { kappa } \\
\text { (к) T1 }\end{array}$ & $\begin{array}{l}\text { kappa } \\
\text { (к) T2 }\end{array}$ \\
\hline$<0$ & Poor agreement & 0 & 0 \\
\hline $0.0-0.20$ & Slight agreement & 0 & 1 \\
\hline $0.21-0.40$ & Fair agreement & 2 & 4 \\
\hline $0.41-0.60$ & Moderate agreement & 5 & 4 \\
\hline $0.61-0.80$ & $\begin{array}{l}\text { Substantial } \\
\text { agreement }\end{array}$ & 4 & 2 \\
\hline $0.81-1.00$ & $\begin{array}{l}\text { Almost perfect } \\
\text { agreement }\end{array}$ & 0 & 0 \\
\hline
\end{tabular}

Table 7: Ranking of script components for 10 clients at T2 assessment

\begin{tabular}{|c|c|c|c|}
\hline Priority & $\begin{array}{l}\text { Script } \\
\text { components }\end{array}$ & $\begin{array}{c}\text { kappa } \\
\text { quota (k) }\end{array}$ & $\begin{array}{l}\text { Agreement } \\
(\%)\end{array}$ \\
\hline 1 & $\begin{array}{l}\text { Game/drama } \\
\text { triangle }\end{array}$ & ${ }^{* *} 0.69$ & 90 \\
\hline 2 & Real feeling & ${ }^{* *} 0.66$ & 90 \\
\hline 3 & $\begin{array}{l}\text { Driver } 1 \text { from } \\
\text { mother }\end{array}$ & ${ }^{* *} 0.52$ & 86 \\
\hline 4 & Racket feeling & ${ }^{* *} 0.49$ & 66 \\
\hline 5 & $\begin{array}{l}\text { Injunction } 1 \text { from } \\
\text { mother }\end{array}$ & ${ }^{* *} 0.46$ & 66 \\
\hline 6 & $\begin{array}{l}\text { Driver } 1 \text { from } \\
\text { father }\end{array}$ & ${ }^{* *} 0.41$ & 70 \\
\hline 7 & $\begin{array}{l}\text { Counterinjunction } \\
1 \text { from father }\end{array}$ & ${ }^{* *} 0.39$ & 66 \\
\hline 8 & Escape hatch & 0.38 & 90 \\
\hline 9 & Life positioner & 0.36 & 83 \\
\hline 10 & $\begin{array}{l}\text { Injunction } 1 \text { from } \\
\text { father }\end{array}$ & 0.29 & 73 \\
\hline 11 & $\begin{array}{l}\text { Counterinjunction } \\
1 \text { from mother }\end{array}$ & ${ }^{*} 0.15$ & 50 \\
\hline
\end{tabular}


Table 8a: Percentage of intra-assessor reliability of 9 clients at the 2 assessment times

\begin{tabular}{c|c|c|c|c}
\hline & $\begin{array}{c}\text { Assessor } \\
\text { A }\end{array}$ & $\begin{array}{c}\text { Assessor } \\
\text { B }\end{array}$ & $\begin{array}{c}\text { Assessor } \\
\text { C }\end{array}$ & $\begin{array}{c}\text { Total } \\
\text { (M) }\end{array}$ \\
\hline Client & & & 68 & 47 \\
\hline $\mathbf{1}$ & 53 & 20 & 80 & 63 \\
\hline $\mathbf{2}$ & 35 & 75 & 79 & 58 \\
\hline $\mathbf{3}$ & 38 & 58 & 56 & 34 \\
\hline $\mathbf{4}$ & 12 & 33 & 71 & 49 \\
\hline $\mathbf{5}$ & 38 & 37 & 54 & 39 \\
\hline $\mathbf{6}$ & 20 & 44 & 68 & 46 \\
\hline $\mathbf{7}$ & 50 & 19 & 82 & 51 \\
\hline $\mathbf{8}$ & 35 & 37 & 43 & 31 \\
\hline $\mathbf{9}$ & 20 & 30 & $\mathbf{6 7}$ & $\mathbf{4 6}$ \\
\hline $\begin{array}{c}\text { Total } \\
\text { (M) }\end{array}$ & $\mathbf{3 3}$ & $\mathbf{3 9}$ & & \\
\hline
\end{tabular}

Table 8b: Ranking of the percentage of intra-assessor reliability of 9 clients at the 2 assessment times

\begin{tabular}{|c|c|c|c|c|}
\hline Priority & $\begin{array}{c}\text { Assessor } \\
\text { A } \\
\text { Client }\end{array}$ & $\begin{array}{c}\text { Assessor } \\
\text { B } \\
\text { Client }\end{array}$ & $\begin{array}{c}\text { Assessor } \\
\text { C } \\
\text { Client }\end{array}$ & $\begin{array}{c}\text { All } \\
\text { Assessors } \\
\text { Client }\end{array}$ \\
\hline 1 & 1 & 2 & 8 & 2 \\
\hline 2 & 7 & 3 & 2 & 3 \\
\hline 3 & 3 & 6 & 3 & 8 \\
\hline 4 & 5 & 5 & 5 & 5 \\
\hline 5 & 2 & 8 & 1 & 1 \\
\hline 6 & 8 & 4 & 7 & 7 \\
\hline 7 & 6 & 9 & 4 & 6 \\
\hline 8 & 9 & 1 & 6 & 4 \\
\hline 9 & 4 & 7 & 9 & 9 \\
\hline
\end{tabular}

Figure 2: Percentage agreement between script analyses made at 2 times by 3 assessors (intra-assessor reliability)

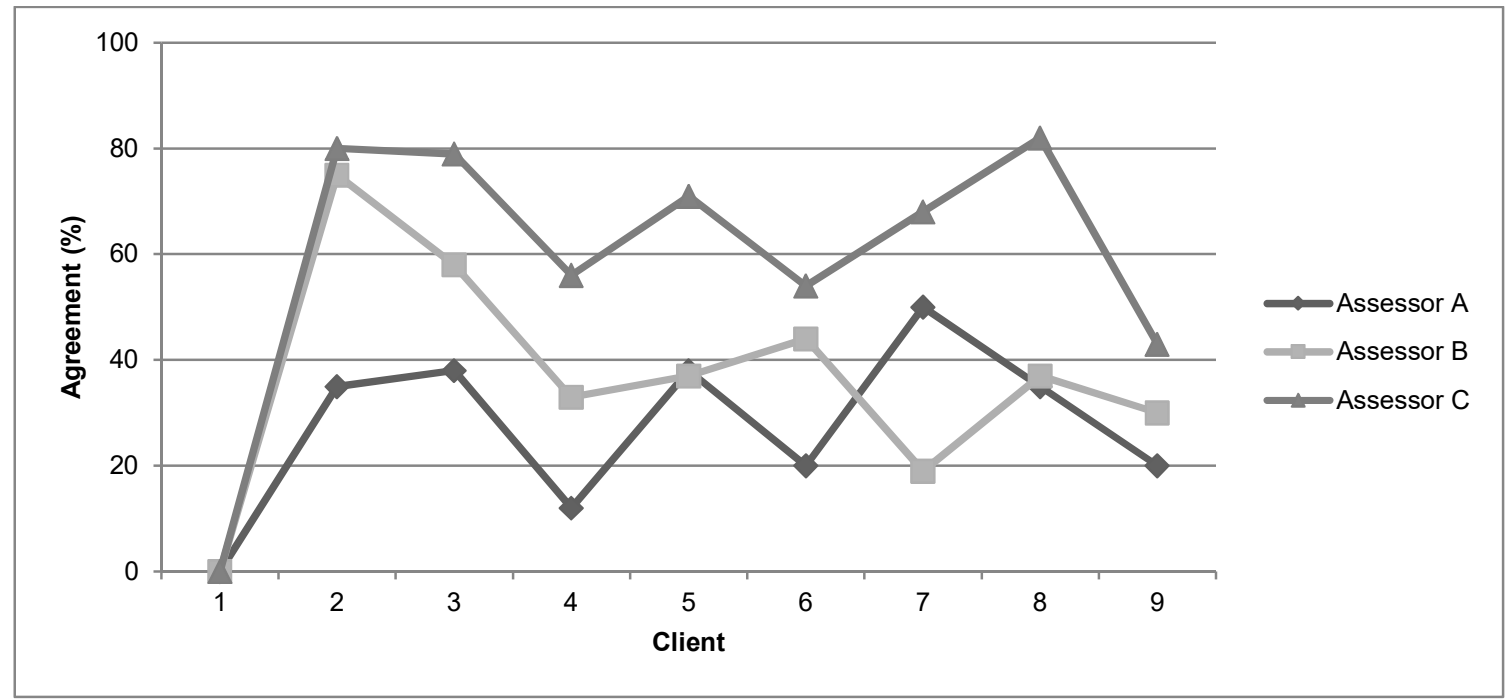


APPENDIX A: Script questionnaire (Ohlsson, Björk \& Johnsson, 1992)

1. Your name:

What does your name mean? How old are you?

2. Describe yourself briefly as you are now.

3. How do you earn your living?

4. How and with whom do you live now?

5. Do you have children? If yes, who are they, and who is the other parent?

6. What is your education and work experience?

7. Tell us what you know about your own birth?

8. Who are your biological parents?

9. Where and with whom did you live as babies?

10. As a $4-5$ year old?

11. When did you begin school?

12. And when were you a teenager?

13. Describe your mother briefly, as she was when you were little?

14. Describe your father briefly, as he was when you were little?

15. What did your mother do when she was displeased with you?

16. What did she do when she was pleased with you?

17. What did your father do when he was displeased with you?

18. What did he do when he was pleased with you?

19. When you were small, what did you like best about your father?

20. As far as you remember, which is the worst memory of your father?

21. And the worst memory of your mother?

22. What did you like best about your mother?

23. What fairy tale or story did you like best as a child?

24. Tell me about the story

25 . What is it that appeals to you in the story?

26. What would you do and how did you feel when you were little and the grown-ups were stupid?

27. Do you remember any time it happened when you were little?

28. How do you think you are going to die? How old will you become? 
29. What do you think people will say about you after your death?

30. What would 'happiness' be for you?

31. What is your biggest problem right now?

32. What is the most common bad feeling you have experienced in your life?

33. Tell me what you think your life will be like in five years.

34. What do you dislike most in yourself?

35. What do you like most about yourself?

36. What was the most important decision in your life?

37. In what way would you have liked your mother to have been different?

38. In what way would you have liked your father to have been different?

39. What kind of a life did your grandparents live? Grandmother/s? Grandfather/s?

40. Tell me which of your parents or grandparents are dead. How did they die and how old were they? Mother? Father? Grandmother/s? Grandfather/s?

41. If you were a magician, what would you want to conjure up in yourself?

42. What of all this do you think you can achieve even though you are not a magician?

43. Do you want to tell us anything else? Is there anything I did not ask that you think I need to know to understand your situation? 
Name:

No:

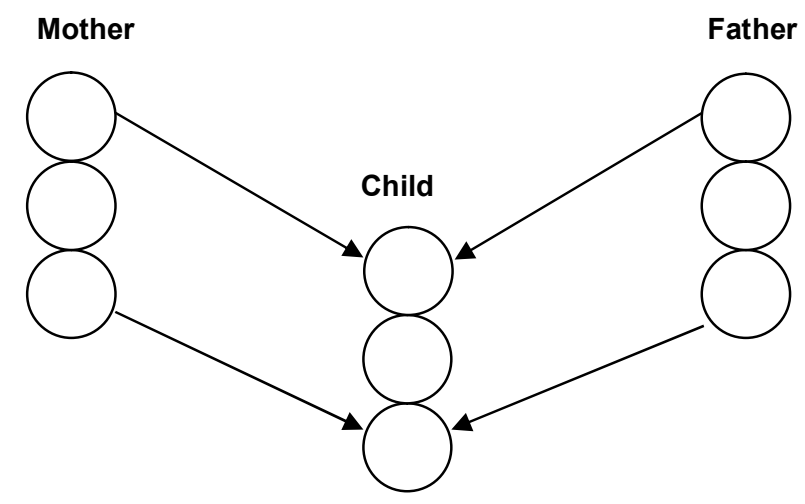

Counterinjunction:

Drivers:

Injunction:

Early decisions:

Racket feeling/Real feeling

Game: (Persecutor, Rescuer, Victim) Specify:

Life position:

Escape hatch:
Counterinjunction:

Drivers:

Injunction: 